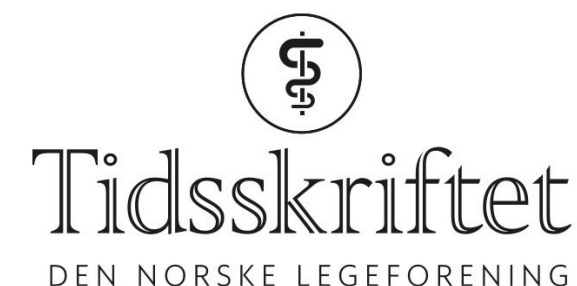

\title{
Rettelse: En mann i 50-årene med magesmerter, kløe og vekttap
}

RETTELSE

KRISTIN HAMMERSBØEN BJØRLYKKE

LARS LOHNE EFTANG

KRZYSZTOF GRZYB

PÅL-DAG LINE

KRISTOFFER LASSEN

JØRGEN JAHNSEN

Tidsskr Nor Legeforen 2020; 140: 268-72.

I Tidsskriftet nr.3/2020 på s. 268 skal arbeidsstedet til Kristoffer Lassen være: Gastrokirurgisk avdeling, Oslo universitetssykehus, Rikshospitalet og Institutt for klinisk medisin, UiT - Norges arktiske universitet.

Vi beklager feilen, den er rettet på nett.

Publisert: 13. mars 2020. Tidsskr Nor Legeforen. DOI:10.4045/tidsskr.20.0137

(C) Tidsskrift for Den norske legeforening 2020. Lastet ned fra tidsskriftet.no 